\title{
EXCESSIVE PRICES: USING ECONOMICS TO DEFINE ADMINISTRABLE LEGAL RULES
}

\author{
David S. Evans and A. Jorge Padilla
}

CEMFI Working Paper No. 0416

September 2004

CEMFI

Casado del Alisal 5; 28014 Madrid

Tel. (34) 914290 551. Fax (34) 914291056

Internet: www.cemfi.es

We have benefited from the comments and suggestions from the participants at the 2003 Lake Como Summit. We have also benefited from numerous conversations with Inmaculada Gutierrez, Anne Layne-Farrar, and Alison Oldale, and the invaluable research support Nese Nasif, Irina Danilkina, and Karen Frazer. We are grateful to Microsoft for financial support of our research. We alone are responsible for the views expressed in this paper. 
CEMFI Working Paper 0416

September 2004

\title{
EXCESSIVE PRICES: USING ECONOMICS TO DEFINE ADMINISTRABLE LEGAL RULES
}

\begin{abstract}
European competition laws condemn as "exploitative abuses" the pricing policies of dominant firms that may result in a direct loss of consumer welfare. Article 82(a) of the EC Treaty, for example, expressly states that imposing "unfair" prices on consumers by dominant suppliers constitutes an abuse. Several firms have been found to abuse their dominant positions by charging excessive prices in cases brought by the European Commission and the competition authorities of several Member States. Those cases show that the assessment of excessive pricing is subject to substantial conceptual and practical difficulties, and that any policy that seeks to detect and prohibit excessive prices is likely to yield incorrect predictions in numerous instances. In this paper we evaluate the pros and cons of alternative legal standards towards excessive pricing by explicitly considering the likelihood of false convictions/acquittals and the costs associated with those errors. We find that the legal standard that maximizes long-term consumer welfare given the information typically available to regulators would involve no ex post intervention on the pricing decisions of dominant firms. A possible exception to this general rule is discussed.
\end{abstract}

JEL Codes: D4, K21, L4.

Keywords: Excessive Pricing, Dominant Firms, EU Competition policy.

David S. Evans

LECG

devans@lecg.com

\author{
A. Jorge Padilla \\ LECG \\ jpadilla@lecg.com
}




\section{INTRODUCTION}

Although the number of excessive pricing cases in the European Union has been relatively limited so far, a few recent cases, both at the European Commission and in some Member States, ${ }^{2}$ suggest an increase in the interest of the competition authorities for this type of antitrust action. It seems therefore appropriate to consider the welfare implications of an activist policy towards excessive prices and, more ambitiously, to inquire what constitutes optimal public policy in this regard.

According to Article 82(a) of the EC Treaty, a firm with market power abuses its dominant position if it "directly or indirectly" imposes "unfair purchase or selling prices or other unfair trading conditions.”3 Roughly speaking, a dominant firm violates Article 82(a) if it charges unfairly high prices to its customers or, alternatively, if it pays unfairly low prices to its suppliers. ${ }^{4}$ These pricing practices would also constitute a Chapter II violation according to Section 18 of the 1998 UK Competition Act, ${ }^{5}$ and likewise would violate the competition laws of the other EU Member States. ${ }^{6}$ These practices are considered to be an "exploitative” abuse because they may result in a direct loss of consumer welfare. ${ }^{7}$

The assessment of the pricing policies of dominant firms from the perspective of Article 82(a) ${ }^{8}$ faces numerous conceptual as well as practical difficulties. Conceptually, what

\footnotetext{
${ }^{2}$ See, for example, the Commission's cases Deutsche Post II OJ [2001] L 331/40 and Duales System Deutschland AG 2001/463 [2001] OJ L166/1; Case CA98/2/2001 Napp Pharmaceuticals Holdings Ltd (30 March 2001) in the UK; Expediente 552/02 Empresas Eléctricas (7 July 2004) in Spain.

${ }^{3}$ Treaty on European Union (Amsterdam Treaty) art 82.

4 In what follows, for expositional simplicity, we will focus on excessively high prices only. Furthermore, this paper focuses on single-dominance abuses and does not cover abuses of collectively dominant positions. Yet our main policy implications are also relevant for the latter type of cases.

${ }^{5}$ Competition Act 1998 (UK) c 41, s 18. Before the Competition Act 1998, the Fair Trading Act of 1973 regulated trading practices. The Competition Act 1998 and the Enterprise Act 2002 have replaced many of its provisions.

${ }^{6}$ By way of comparison, there is no comparable cause of action against “excessive prices” in the United States. See, generally, P Areeda and H Hovenkamp III Antitrust Law (Little, Brown and Company Boston Mass 1996).

${ }^{7}$ EC competition law and the competition laws of the Member States also condemn as abusive those pricing policies, including excessive pricing, that result in the "exclusion" of competitors from the market, as they may harm consumers indirectly.

${ }^{8}$ Also for expositional simplicity, we will refer to Article 82(a) as a shortcut for all relevant EU competition legislation in connection with "unfair" pricing.
} 
constitutes "unfair" pricing has been the subject of a long and heated debate between policy makers, academics, and courts. ${ }^{9}$ From a practical perspective, the question is how competition policy authorities and courts could distinguish between competitive prices and unfairly high prices. The answers to these questions are of the utmost importance since the actual effect on consumer welfare of regulatory interventions on the pricing policies of dominant firms depends on the ability of competition policy authorities and courts to establish whether or not prices are excessive in practice.

Economic theory shows that markets are most efficient when prices are "competitive.” At higher prices, consumers are made worse off and overall welfare is reduced. At lower prices, firms fail to receive an appropriate return on their investments, which results in insufficient entry and/or inefficient exit. ${ }^{10}$ A policy that could identify and punish deviations from the competitive benchmark without error would increase social welfare unambiguously. Unfortunately, it is unclear what the appropriate competitive benchmark is in most real-life circumstances and, particularly, in dynamic industries where investment and innovation play a paramount role. ${ }^{11}$ Moreover, even if an appropriate benchmark could be defined, it would still remain unclear how one could, on the basis of the information typically available to policy makers and industry analysts, determine with precision whether prices are above, at, or below the competitive benchmark in practice.

Consequently, any policy that seeks to detect and prohibit excessive prices in practice is likely to yield incorrect predictions. In some instances, the authorities may conclude that prevailing market prices are competitive when they are not. In some others, they may conclude that prices are excessive when in reality they are competitive. All these errors are costly. In the first set of cases_or, false acquittals_output is lower than optimal: some consumers are

\footnotetext{
${ }^{9}$ See, for example, Napp (n 2); Case 27/76 United Brands v Commission [1978] ECR 207, [1978] 1 CMLR 429; SO Spinks 'Exclusive Dealing, Discrimination, and Discounts under EC Competition Law' (2000) 67 Antitrust LJ 641; JT Lang and R O’Donoghue 'Defining Legitimate Competition: How to Clarify Pricing Abuses under Article 82 EC' (2002) 26 Fordham Intl LJ 83; EM Fox 'What is Harm to Competition? Exclusionary Practices and Anticompetitive Effect' (2002) 70 Antitrust LJ 371.

${ }^{10}$ ML Katz and HS Rosen Microeconomics ( $3^{\text {rd }}$ edn Irwin/McGraw-Hill Boston Mass 1998) c 11.

${ }^{11}$ See DS Evans and R Schmalensee 'Some Economic Aspects of Antitrust Analysis in Dynamically Competitive Industries' in AB Jaffe J Lerner and S Stern (eds) NBER/Innovation Policy and the Economy: Volume 2 (MIT Press Cambridge Mass 2002).
} 
forced out of the market when they should have not. In the second set of cases-or, false convictions-profits are kept artificially low, which reduces the incentives to invest and innovate to the ultimate detriment of consumers. ${ }^{12}$

The choice of policy towards excessive prices should, in principle, be the result of a pragmatic analysis of which type of error is (a) more likely and (b) more costly. In this paper our objective is to conduct such an analysis in order to characterize optimal public policy towards excessive prices taking into account that false convictions and/or false acquittals are likely to be the norm rather than the exception.

The paper is structured as follows. In Section 2, we present the various notions of unfair prices that have been used in the European competition policy debate. In Section 3, we assess how the existing policy towards excessive prices has been implemented in practice with the help of two seminal cases: one EC case-United Brands ${ }^{13}$ - and one UK case-Napp. ${ }^{14}$ In Section 4, we present our first result: that there is no pricing rule or benchmark that can be used to distinguish effectively (i.e., without error) between competitive and excessive prices in practice. In Section 5, we explore the implications of this "impossibility theorem" for the design of an administrable legal standard towards excessive prices. ${ }^{15}$ In particular, we consider the likelihood and costs of the errors associated with an interventionist policy, and evaluate the pros and cons of various legal rules: per se legality, modified per se and illegality, (structured) rule of reason, etc.

We find that, in general, consumers are best served with a policy that leaves firms, including dominant firms, free to charge prices above cost and earn positive, and possibly high, profits. This is especially the case in industries where innovation and investment plays a central role. There is, however, one possible exception to this pragmatic rule that may justify retaining Article 82(a) and its counterparts in the legislations of the Member States. This exception refers

\footnotetext{
${ }^{12}$ R Crandall and JH Alleman (eds) Broadband (AEI-Brookings Washington DC 2002).

${ }^{13}$ United Brands (n 9).

${ }^{14}$ Napp (n 2).

${ }^{15}$ On the importance of "administrability”, see T. J. Muris 'Improving the Economic Foundations of Competition Policy’ George Mason Law Review’s Winter Antitrust Symposium (15 January 2003).
} 
to situations where the dominant firm enjoys a legal monopoly and the excessive prices charged by the goods and services offered by the legal monopolist are likely to prevent the launching of new products or the emergence of adjacent markets. This exception is consistent with the Commission's practice in General Motors and British Leyland. ${ }^{16}$ However, it remains unclear why competition policy constitutes appropriate public policy even in this case, and why it may not be better simply to regulate the prices of the legal monopolists ex ante. This is discussed in Section 6. Section 7 concludes with a brief comparison of the EU and US approaches to excessive pricing in light of our previous results.

\section{DEFINING “UNFAIR” PriCES}

There is no generally accepted definition of what an "unfair" price is. For Marxist economists the "fair" price of a product is equal to the value of labor involved in its production. ${ }^{17}$ Classical economists like David Ricardo also held a cost-based theory of value. ${ }^{18}$ For neo-classical economists, the "fair" value of a good or service is given by its "competitive" market price, which is the equilibrium price that would result from the free interaction of demand and supply in a competitive market. ${ }^{19}$ This was also the interpretation given to the notion of "fair" prices by Scholastic economic thought, ${ }^{20}$ and is also the interpretation used by the ordo-liberal school of economic thought, which had a major impact on the development of competition policy in Europe. ${ }^{21}$ For the ordo-liberals, a price is "fair" when it is the result of “free and honest” competition. Dominant firms should set "competitive” prices, i.e., they should act "as if" they operated in competitive markets. ${ }^{22}$ The question arises as how do we define what a "competitive" price is in practice.

\footnotetext{
${ }^{16}$ General Motors OJ [1975] 1 29/14 1 CMLR D20; British Leyland OJ [1984] L 207/11.

${ }^{17}$ K Marx Capital (Frederick Engels ed 1887).

18 JA Schumpeter History of Economic Analysis (E Boody Schumpeter ed Oxford University Press Oxford 1954) pt III, c 4.

${ }^{19}$ Alfred Marshall Principles of Economics (Macmillan London 1890).

${ }^{20}$ Schumpeter (n 18) pt II, c 2.

${ }^{21}$ DJ Gerber Law and Competition in Twentieth Century Europe: Protecting Prometheus (Oxford University Press Oxford 1998).

${ }^{22}$ This is the precise formula for unfair prices adopted by German Competition Law para 19, s 4, n 2 GWB.
} 
In static, competitive industries where investment is the exception rather than the norm and where production is not subject to significant economies of scale, the "competitive" price is given by the incremental cost of production given market demand. At those prices, all consumers with willingness to pay in excess of the incremental cost of production get to buy the goods or services traded in the market. At higher prices, there are consumers who value the goods and services more than their costs of production who can no longer afford them. An increase in prices above the competitive level has therefore two negative effects on consumer welfare: First, it transfers rents from consumers to firms, as every consumer who purchases the goods and services in offer pays more for them than in a competitive market. Second, it destroys rents by forcing out of the market some consumers with relatively modest valuations.

But competition is rarely static and industries often exhibit significant economies of scale and/or scope. In dynamic industries, where typically fixed costs are high and incremental costs are low, the "competitive" price is not given by marginal costs. Rather, it is efficient to charge prices according to customers' willingness to pay so as to cover fixed costs in the least output restricting way. ${ }^{23}$ In short in these industries it is impossible to define "competitive" prices using only information on costs.

Some economists have tried to avoid these difficulties by relying on profit benchmarks, rather than price-cost benchmarks, in the assessment of excessive prices. ${ }^{24}$ Under this alternative approach the prices of a particular firm are deemed "excessive" if the firm obtains profits higher than it could expect to earn in an otherwise identical competitive market. That is, if the dominant firm's return on capital is greater than its weighted average cost of capital. However, in practice, there are considerable conceptual and estimation problems in measuring these variables.

For example, accounting complications result when considering pricing strategies designed to maximize the sales of a group of related goods and services rather than a single

\footnotetext{
${ }^{23}$ C Ahlborn, D. S. Evans and A. J. Padilla 'Competition Policy in the New Economy: Is European Competition Law Up to the Challenge?’ (2001) 5 ECLR 156, 164.

${ }^{24}$ Review of the Impact of the Financial Services and Markets Act 2000 on Competition (Office of Fair Trading March 2004).
} 
product. Further complications arise when the manufacturing of the product under analysis is undertaken in parts by multiple company divisions, across multiple countries, over multiple years, and perhaps relying on intellectual property resulting from considerable past $\mathrm{R} \& \mathrm{D}$ expenditures on an unrelated technology. Even if one could devise meaningful accounting rules for approximating the return on capital and the weighted average cost of capital, deciding among the various available options would always be arbitrary.

Measurement issues are the least of the concerns with using profit benchmarks, though. Accounting procedures do not provide for capitalization of $R \& D$ and advertising, do not address inflation, and do not properly adjust rates of return for risk. ${ }^{25}$ Thus accounting profits do not reflect economic profits except under the most unrealistic assumptions. ${ }^{26}$ The relationship between accounting and economic rates of return hinges on the time shape of net revenues, something that varies across industries, across firms within an industry, and even across time for a given firm. ${ }^{27}$ Nor can the divergence between the two rates be assumed away as small. As Fisher and McGowan illustrate with their calculations, "there is no way in which one can look at accounting rates of return and infer anything about relative economic profitability or, a fortiori, about the presence or absence of monopoly profits.”28

These problems become particularly severe in industries where firms invest and innovate regularly. ${ }^{29}$ In those industries a few companies succeed but the winners typically obtain enormous profits. Those profits would appear excessive ex post, when the innovations are commercialized. However, from an ex-ante perspective and once the cost of capital is adequately adjusted for risk, competitors may earn normal profits: the huge profits earned by

\footnotetext{
${ }^{25}$ Gerald Salamon also finds that the accounting rate of return contains systematic measurement error. Firm size, control type (management versus ownership, for example), and accounting methods were all found to influence the calculated accounting return. GL Salamon 'Accounting Rates of Return' (1985) 75 American Economic Rev 495.

${ }^{26}$ FM Fisher and JJ McGowan 'On the Misuse of Accounting Rates of Return to Infer Monopoly Profits' (1983) 73 American Economic Rev 82.

${ }^{27}$ Ibid.

${ }^{28}$ Ibid 90.

${ }^{29}$ Ahlborn Evans and Padilla (n 23) 163-4.
} 
the winner(s) may compensate for the huge loses made by all those who fail. ${ }^{30}$ Our point is not that firms do not earn monopoly profits. Some surely do. It is that it is very hard to say when this is the case and to quantify how much of the profits-and therefore how much of the prices-are the result of monopoly rather than competitive tactics.

In sum, the "excess profits" approach to the identification of excessive pricing is no less controversial than the direct price-cost approach. This is recognized implicitly by the OFT's Draft Guidelines on the Assessment of Conduct:

It is unlikely that a dominant undertaking would be found to have charged excessive prices solely on the evidence of supra-normal profitability. The analysis would usually consider other indicators, such as the cost and price comparators described above. ${ }^{31}$

\section{CASe Law Illustrations}

In this Section we briefly review two seminal cases that illustrate the difficulty of deciding what constitutes an excessive price. These two leading cases had very different outcomes. In one case the economic evidence was considered insufficient to sustain a finding of excessive prices; in the other, the appeals court reached the opposite conclusion.

The first case, United Brands, is one of the few cases on excessive pricing under EC competition law. ${ }^{32}$ In this case, the European Court of Justice (ECJ) quashed the Commission's decision because it considered the economic analysis performed subjective, incomplete and flawed. ${ }^{33}$ The ECJ stated that a price is excessive when it "has no reasonable relation to the economic value of the product supplied.”34 The Court, recognizing perhaps that such a

\footnotetext{
${ }^{30}$ See J Lerner 'The Returns to Investments in Innovative Activities: An Overview and an Analysis of the Software Industry' in DS Evans (ed) Microsoft, Antitrust and the New Economy: Selected Essays (Kluwer Academic Publishers Boston Mass 2002); J DiMasi H Grabowski and J Vernon 'Returns on R\&D for 1990s New Drug Introductions' (2002) 20 PharmacoEconomics 11. See also H Grabowski and J Vernon 'Returns to R\&D on New Drug Introductions in the 1980s’ (1994) 13 J Health Economics 383.

${ }^{31}$ Assessment of Conduct, Draft Competition Law Guideline for Consultation (Office of Fair Trading April 2004) para 2.15 (henceforth referred to as Assessment of Conduct).

${ }^{32}$ Case IV/2669 Chiquita OJ [1976].

${ }^{33}$ United Brands (n 9).

${ }^{34}$ Ibid.
} 
definition was not operational per se, went on to clarify what is necessary under EC law to deem excessive the prices charged by a dominant firm.

The second case, Napp, is much more recent. This was the first excessive pricing case tried under the UK 1998 Competition Act. ${ }^{35}$ The Office of Fair Trading (OFT) argued in its 2001 decision that Napp was dominant in the market for sustained release morphine and that the prices charged by Napp to some consumers were excessive. The case was upheld on appeal by the UK Competition Commission Appeals Tribunal (CCAT). ${ }^{36}$

\subsection{United Brands}

In 1975, United Brands (UBC) was the largest banana company in the world: its main brand was Chiquita bananas. UBC shipped bananas to the EU through two main ports, Bremerhaven and Rotterdam. The fruit then needed to be ripened by specialist ripeners. UBC accounted for 45 percent of bananas sold in Belgium, Luxembourg, Denmark, Germany, Ireland and the Netherlands. These Member States were taken to be a unified relevant geographic market for the analysis of this case.

The European Commission considered in its decision ${ }^{37}$ that UBC had a dominant position in bananas on the relevant geographic market, and that it had committed four abuses: (a) preventing its distributors/ripeners from reselling bananas while still green; (b) price discriminating between the Scipio group (with which UBC had a particularly close business relationship) and other distributors/ripeners; (c) imposing unfair (i.e. excessive) prices for the sale of Chiquita bananas for customers (other than the Scipio group) in Belgium, Luxembourg, Denmark and Germany; and (d) refusing to supply to a particular Danish customer. Only that part of the decision that deals with excessive pricing is described here.

Notably, the Commission placed great emphasis on price differentials between Member States even in the context of its discussion of excessive pricing. Various comparators were used

\footnotetext{
${ }^{35}$ See (n 5).

${ }^{36}$ Case No. 1001-1/1/01 Napp Pharmaceutical Holdings v. Director-General of Fair Trading (Napp Appeal) UK Competition Commission Appeal Tribunal (15 January 2002).

${ }^{37}$ Chiquita (n 32).
} 
to establish that UBC's prices to customers (other than the Scipio group) in Belgium, Luxembourg, Denmark and Germany were excessive. The Commission looked at price discrepancies between branded and unbranded bananas, finding that Chiquita bananas were sold at a premium of 30-40 percent to UBC's unbranded bananas. The "competition comparator” was also used, finding that Chiquita bananas were slightly more expensive than bananas sold by competitors.

But the key exercise was the comparison of UBC’s prices across Member States. UBC's lowest prices were charged to Ireland. In an internal document, UBC appeared to acknowledge that a profit was still made on these sales, which would obviously seem to set an upper bound on UBC's costs (UBC did later deny the Ireland profitability claim). The Commission reasoned that prices for Dublin must include the costs of delivery to Rotterdam and the additional cost of delivery from there to Dublin. Prices to Denmark, the Netherlands, Belgium, Luxembourg and Germany were almost twice as high.

The Commission decided that UBC's price outside Ireland was excessive by 15 percent. No reasoning appears in the decision as to how the 15 percent figure was reached. Furthermore, the Commission did not attempt to establish UBC's production costs in determining a "fair" price. Its sole determination of cost was dependent on the supposed profitability of banana sales in Ireland. Taking into account all four abuses, a fine of 1 million ecus was imposed.

UBC appealed to the ECJ. ${ }^{38}$ UBC claimed it had made losses in Ireland during the period under analysis. It also claimed that it had failed to earn any profits on the relevant market in the period from 1973 to 1978 (save in 1975). The Court determined, among other things, that the fair price

could, inter alia, be determined objectively if it were possible for it to be calculated by making a comparison between the selling price of the product in question and its cost of production, which would disclose the amount of the profit margin; however, the Commission has not done this since it has not analyzed UBC's costs structure. ${ }^{39}$

\footnotetext{
${ }^{38}$ United Brands (n 9).

${ }^{39}$ Ibid 251.
} 
The ECJ concluded that the use of the prices charged in Ireland as a proper cost benchmark was at least open to doubt, noting

there is doubt which must benefit the applicant, especially as for nearly 20 years banana prices, in real terms, have not risen on the relevant market. ${ }^{40}$

The Court acknowledged that

Other ways may be devised-and economic theorists have not failed to think up several_-of selecting the rules for determining whether the price of a product is unfair." ${ }^{41}$

Yet it pointed out that UBC's prices were only 7 percent above those of competitors, "which cannot automatically be regarded as excessive and consequently unfair." 42 The Court annulled that portion of the Commission's decision that dealt with excessive prices. The other three abuses were upheld. The fine was reduced from 1 million to 850,000 ecus.

\subsection{Napp}

In 2001, the Office of Fair Trading investigated Napp Pharmaceutical Holdings under the 1998 UK Competition Act. Napp is a UK based pharmaceutical company. It was the first to launch a sustained release morphine product (MST) in the UK in 1980, and held a patent on the drug through 1992. At one point there were three other suppliers in the market besides Napp, and two remained in the market at the time of the case.

In the market for sustained release morphine tablets, there are two customer segments: the so-called community (or general practitioner) and hospital segments. Approximately 86-90 percent of the market is supplied by wholesalers to community pharmacies to be used by patients as prescribed by their primary care physicians, while 10-14 percent is purchased directly by hospitals from manufacturers to be used for in-patient care as prescribed by hospital doctors or specialists. Napp had market share in excess of 90 percent in both consumer segments. When put together with the considerable barriers to entry into the relevant markets,

\footnotetext{
${ }^{40}$ Ibid 265.

${ }^{41}$ Ibid 253.

42 Ibid 266.
} 
the OFT decided that Napp had market dominance. The OFT found Napp’s pricing policies for MST to be both predatory and excessive. Napp’s practice of pricing the drug at a very low level in the hospital segment was ruled predatory, and its pricing at a high level in the community/general practitioner segment was ruled excessive.

The OFT stated that, under the UK Competition Act of 1998, a price is considered excessive

if it is above that which would exist in a competitive market and where it is clear that high profits will not stimulate successful new entry within a reasonable period. $^{43}$

According to the OFT, the method for ascertaining whether a price is above what would otherwise exist in a competitive market can be approached in two ways: by benchmarking price-cost margins, and by benchmarking prices. The OFT did both. ${ }^{44}$ In benchmarking pricecost margins, the OFT compared Napp’s profit margins across the two consumer segments and also compared its profit margins to those of competitors. Napp earned 40-60 percent margins for the hospital segment and in excess of 80 percent profit margins for the community segment. ${ }^{45}$ Napp's next most profitable competitor earned "less than 70 percent" in the community segment. ${ }^{46}$

The OFT also compared Napp's prices to those of competitors. The OFT found that in the community segment, Napp's prices were 33-67 percent higher than those of its competitors in 2000. ${ }^{47}$ Napp's prices were also compared to its own prices over time: Napp's prices for the community segment did not change for 10 years after patent expiration. ${ }^{48}$ In comparing Napp’s prices to its own prices within and outside the UK, the OFT found that Napp's community

\footnotetext{
${ }^{43} \operatorname{Napp}(\mathrm{n} 2) 203$.

${ }^{44}$ Ibid.

${ }^{45}$ Ibid 224.

${ }^{46}$ Ibid 226.

${ }^{47}$ Ibid 207.

${ }^{48}$ Ibid 213.
} 
segment charges were over 10 times more than hospital prices, ${ }^{49}$ and between 4 and 7 times higher than export prices. ${ }^{50}$

Napp was fined £3.21 million for an abuse of dominant position. The company was required to increase its hospital prices to a level which covered average total costs, and was also ordered to reduce its prices by 15 percent to the National Health Service, a publicly funded program of the UK Department of Health, for MST sold through chemists.

Napp took issue with the OFT's conclusions. ${ }^{51}$ The case was upheld on appeal before the UK Competition Commission Appeals Tribunal (CCAT) in 2001, but the fine was reduced to $£ 2.2$ million. $^{52}$ Napp claimed that the OFT had not taken proper account of the dynamic nature of competition in the market. It argued that "overall rates of return are well within reasonable limits for an industry of this kind," and that the OFT erred in its approach when stating that "competition should drive prices down to reflect long run marginal costs of manufacture, marketing, and distribution, and that any price above that level is excessive.”53 Napp stressed the importance of ex ante uncertainty and dynamic competition. It then argued that prices in a dynamically competitive market would allow recovery of past investments in R\&D and promotion:

over the life cycle of the product as a whole, provides pharmaceutical firms... with the appropriate incentive to invest in such $R \& D$, education, training, and promotion to the extent that consumers collectively are willing to fund such investment. Any such competitive price will take account of the ex ante uncertainty as to whether a particular product will succeed. ${ }^{54}$

\footnotetext{
${ }^{49}$ Ibid 217.

${ }^{50}$ Ibid 221.

${ }^{51}$ With respect to the facts of the case, Napp argued that in real terms the price of MST had fallen by approximately 63 percent since launch in 1980. This seems to have been ignored by the OFT and the CCAT.

${ }^{52}$ Some of this reduction was due to various aspects of the excessive pricing claim, both procedural and due to the fact that "there has been no decided case at Community level upholding an abuse of excessive pricing in circumstances comparable to the present case, and the principles upon which a price is to be judged 'unfairly high' for the purposes of the Chapter II prohibition have not been considered in any previous decision of the Director or the Tribunal," but did not elaborate on what "circumstances" were relevant nor on why the lack of precedent should affect the determination of penalties in this case. Napp Appeal (n 36) 533.

53 Ibid 355-356.

${ }^{54}$ Napp's notice of appeal, quoted in ibid 354.
} 
Napp reasoned that any assessment of whether prices are excessive must take into account ex ante uncertainty, noting specifically that the pharmaceutical industry

is a research-based, innovative industry, in which a few successful 'winners' must not only repay their own development and promotion costs, but must also fund the research and development of a large number of other products which do not cover their own costs, as well as ongoing research into new products, very many of which ultimately turn out to be unsuccessful. ${ }^{55}$

Napp went on to argue that ex ante uncertainty meant that Napp's pricing should be assessed according to a "portfolio-based approach," where prices and profitability for a range of different products are jointly assessed. ${ }^{56}$

The OFT and the CCAT addressed some of the points made by Napp. Although the OFT accepted that there must be some cost recoupment through the patent period, after expiration such recoupment should decline. With regard to Napp’s arguments about the need to apply a 'dynamic' concept of competition, the OFT claimed,

such arguments cannot serve as a justification for a product to earn a limitless stream of monopoly profits through keeping out competitors. When a monopoly comes to an end, whether due to the expiry of a patent or otherwise, and competitive entry occurs, this will normally have some impact on prices...most branded pharmaceutical products suffer very extensive falls in market share when they come off patent. ${ }^{57}$

The CCAT agreed, noting,

Napp's original investment in MST was made in the early 1980s in launching and promoting a product which, at the time, represented an important innovation, [but] Napp has provided no figures as to what that initial investment was. In the absence of any indication to the contrary, we would expect that initial investment to have been recouped long ago. ${ }^{58}$

\footnotetext{
55 Ibid 356-357.

${ }^{56}$ Ibid 357, 361.

${ }^{57}$ Ibid 367, 369.

${ }^{58}$ Ibid 407.
} 
Furthermore, the OFT and the CCAT argued that while brand value may involve a price premium, such a premium could not be as high as 40 percent (as noted above, Napp's prices were 33-67 percent higher than those of its competitors).

The CCAT also rejected the arguments that ex ante uncertainty justified high ex post prices. In particular, regarding the "portfolio pricing" version of the argument, the CCAT stated,

[I]t is not appropriate ... to take into account the reasonableness or otherwise of its profits on other, unspecified, markets comprised in some wider but undefined 'portfolio' unrelated to the market in which dominance exists. ${ }^{59}$

\subsection{The ECJ and CCAT tests}

Two very different standards emerge from these cases, but as we will argue none of them is satisfactory as a matter of economics.

In United Brands, the ECJ stated,

The questions therefore to be determined are whether the difference between the costs actually incurred and the price actually charged is excessive, and, if the answer to this question is on the affirmative, whether a price has been imposed which is either unfair in itself or when compared to competing products. ${ }^{60}$

This is a two-step test. ${ }^{61}$ First, the test requires comparing actual costs and prices. Second, the test requires determining whether a price is excessive in itself or by comparison to competitors' products. ${ }^{62}$ The ECJ applied this test to quash the Commission's United Brands

\footnotetext{
${ }^{59}$ Napp Appeal (n 36) 413. The Commission went on to stress that "in the case of many pharmaceutical products, the expiry of a patent leads to competitive (often generic) market entry...In the present case, however, Napp has maintained both the price of MST and an exceptionally high market share for many years [emphasis in original]." Ibid 417.

${ }^{60}$ United Brands (n 9) 252. Motta and de Streel argue that (a) these two steps "should not necessarily be used cumulatively," and (b) the direct cost calculation enjoys priority. See M Motta and A de Streel 'Exploitative and Exclusionary Excessive Prices in EU Law' in CD Ehlermann and I Attanasiu (eds) European Competition Law Annual 2003: What Is an Abuse of Dominant Position? (Hart Publishing Oxford, forthcoming.)

${ }^{61}$ C Esteva-Mosso and S Ryan 'Article 82-Abuse of Dominant Position' in J Faull and A Nikpay (eds) The EC Law of Competition (Oxford University Press Oxford 1999) c 3, 190.

${ }^{62}$ In Deustche Grammophon 78/70 [1971] ECR 487, the ECJ stated that a finding of excessive prices could be based on a price comparison between two competitors. See also, SACEM II 110/88, 242/88 [1989] ECR 2811, para 25.
} 
decision. First, the Court noted that the Commission had failed to analyze UBC's costs—a task that was regarded as manageable in this particular case. Furthermore, the Court considered that the price differential with UBC's competitors was immaterial and so concluded that the Commission had failed to establish the second part of the test.

It is unclear, however, how this test could be applied more generally and what forward guidance it effectively provides for competition authorities and dominant firms. The first limb of the test is difficult to work out in practice. It is one thing for a regulatory agency that specializes in an industry, has a staff of accountants who can examine company books and economists who can do cost studies. It is quite another for competition authorities or courts to do so.. ${ }^{63}$ But the second limb is the more problematic one as there is no reliable standard for determining a "competitive" profit margin in most industries. That is especially true for industries that form an increasing part of modern economies: those based on intellectual property, significant fixed costs, and dynamic competition. In fact, casual business experience indicates that virtually all businesses charges prices that exceed short-run marginal costs. Thus marginal costs, even if they can be measured, provide scant guidance in real-world industries. ${ }^{64}$ The second limb of the test is not only highly ambiguous, as the first limb is, but also entirely subjective. When can it be said that a price is excessive in "itself"? There is no objective response to this question; any possible answer would involve a value judgment. And this is not the only "impossible" question: What competing products should be taken in consideration in the analysis of excessive prices? How can one make sure that one is comparing like with like? What if the prices charged by competitors are excessively high too? And what if they are regarded as predatory?

In Napp the OFT adopted what could be termed as a "preponderance-of-the-evidence" approach to the analysis of excessive prices. This approach, which has now been described in

\footnotetext{
${ }^{63}$ See s 2 above.

64 See WJ Baumol and DG Swanson 'The New Economy and Ubiquitous Competitive Price Discrimination: Identifying Defensible Criteria of Market Power' (2003) 70 Antitrust LJ 661; and B Klein and JS Wiley Jr 'Competitive Price Discrimination as an Antitrust Justification for Intellectual Property Refusals to Deal' (2003) 70 Antitrust LJ 599.
} 
detail in the OFT's Draft Guidelines on the Assessment of Conduct, ${ }^{65}$ consists in the use of several cost, price and profitability benchmarks. The CCAT considered that the methods employed by the OFT were

among the approaches that may reasonably be used to establish excessive prices, although there are, no doubt, other methods ... no serious criticism can be made of the detail of the price comparisons relied on by the [OFT] Director. ${ }^{66}$

The CCAT also seems to have approved the OFT’s “preponderance-of-the-evidence” standard:

in our view those [price and margin] comparisons, taken together, amply support the Director's conclusions that Napp's prices were ... well above what would have been expected in competitive conditions. ${ }^{67}$

The question is why should the answers to several ambiguous tests-even if mutually consistent-be more credible than the answer to one ambiguous test. The comparisons performed by the OFT in Napp were no less controversial than those performed by the Commission in United Brands.

For example, the OFT used Napp’s prices while enjoying patent protection as a proxy for supra-competitive prices, reasoning that since we expect a sanctioned monopolist to charge excessive prices, the prices charged after the patent expired must have thus been excessive. While it is true that patent law grants firms a certain period of time in which to recoup up-front costs, that time period is no magic number. There is no reason to believe that the exact number of years under a patent is the time necessary to fully recoup the investment costs and provide sufficient incentives to innovation. And there is no reason to suggest that prices should suddenly revert to marginal cost once the legally sanctioned monopoly is over. Traditionally, once patent protection expires, generic drug manufacturers step in as competitors. Although they have invested less than the brand names generic manufacturers still incur fixed costs of

\footnotetext{
${ }^{65}$ Assessment of Conduct (n 31).

${ }^{66}$ Napp Appeal (n 36) 366, 392-396.

${ }^{67}$ Ibid 397.
} 
entry and they maintain prices that are likely to be well in excess of the marginal cost of producing drugs (which is typically small). ${ }^{68}$

Consider now other price comparisons performed in this case. Napp charged more to the community segment than it did to the hospital segment, but it is clear that this comparison by itself cannot prove excessive prices. Napp’s low hospital prices were themselves being challenged as too low, which should by itself invalidate the hospital segment prices as a comparison standard. Napp's competitors offered substitutes that were also above Napp's hospital segment prices. Clearly the hospital segment price is invalid as a standard for what a “competitive” price would be in the market. The prices charged by Napp's competitors' to the consumer segment were lower than Napp's consumer segment price, but as proof of "excessive prices” this fact does not hold up to economic analysis. Napp's product had been the market standard for two decades, so surely it had both brand recognition and consumer trust; yet the OFT decided that brand recognition was not worth 40 percent. Besides the fact that brand-name medicines routinely cost multiples over that of their generic counterparts, any hard-and-fast number as a standard for "excessive” brand name value would be arbitrary. These comparisons by themselves are weak.

\section{A FOLK IMPOSSIBILITY THEOREM}

The conceptual problems and practical difficulties faced by competition authorities and courts in United Brands and Napp are not mere anecdotes. Instead, they are two concrete manifestations of a more fundamental problem, which we express in the form of the following “impossibility” statement:

There is no price-cost or profitability benchmarking rule that implements Article 82(a) (or its counterparts in the Member States) in a manner that satisfies the following two conditions: (a) objectivity and (b) efficiency.

To explain why this is the case, consider the following general benchmark rule: a price (or a profit rate) is excessive in the sense of Article 82(a) if it is greater than a given

\footnotetext{
${ }^{68}$ See DS Evans and M Salinger 'An Empirical Analysis of Bundling and Tying: Over-The-Counter Pain Relief and Cold Medicines' Prepared for CESifo Summer Institute 2004 meeting on 'Recent Trends in Antitrust' Venice Italy (21-22 July 2004).
} 
comparator. To be objective the rule would have to (1) specify what measure of "price" and "profit" would be employed in the comparison, (2) identify an unambiguous and workable “comparator," and (3) define a "critical threshold" for the price or profit variable. The rule could specify different terms according to the type of economic activity under analysis, but it would have to do so ex ante in an objective way.

For example, if the benchmark were given by the prices charged by competitors, the rule would have to define what prices would be compared, which is a non-trivial requirement in differentiated product industries. It would also have to specify which competitors would be taken into consideration, in which countries, and over which period of time. And, in addition, it would have to determine what the "critical" price differential is.

An objective rule yields predictable outcomes and, therefore, it ensures legal certainty. This is crucial, as otherwise firms would not know on which side of the law they are. Predictability avoids chilling effects on business investment. An unpredictable regulatory regime would not merely create ex post results that are unjust by their inconsistency, but have potentially large ramifications for product investment decisions ex ante.

To be efficient, the general benchmark rule described above would have to find that prices are excessive only when set at levels that reduce the static and dynamic efficiency of the market to the detriment of consumers, i.e., when they cause consumer harm taken over the long run.

After several decades of debating how to regulate utilities and other natural monopoly/oligopoly industries, it should be clear that there is no way to satisfy those two requirements—objectivity and efficiency_in practice. The appropriate notions of price, profit and cost, as well as the critical threshold, would have to be tailored to the case at hand in ways that are hard to anticipate before the fact. And even if the particular features of the case were well understood, those choices would remain highly controversial and subject to value judgments.

Utilities regulation is rife with examples of failed price and profit rules. For instance, in the early part of the $20^{\text {th }}$ century, regulators in the United States tried profit sharing for electric 
utilities to keep those firms from reaping "excessive” returns, but had to abandon the practice in the 1950s when the regulated utilities ran up losses. ${ }^{69}$ In telecommunications, regulators around the world have tried to use long-run incremental cost measures (specifically, TELRIC) as a benchmark for prices. But the practice is highly controversial and prone to error. As one observer notes, these cost proxy models miss "firm specific peculiarities on input prices, demands, etc., and therefore will not accurately measure the efficient costs of a specific telecommunications utility."70 Many of the latest utility models center on price caps, but these too, can cause problems. In the U.K., price caps on British Telecom services were blamed for quality deterioration because the caps provide strong incentives for cost-reductions. ${ }^{71}$ ] A generation ago one might argue that telecoms and other regulated industries were the most complicated ones, and that the task is easier for many manufacturing businesses. But today the most dynamic part of the economy is occupied by businesses that are quite complex.

Of course, one could always define an objective rule by specifying, for example, that a firm is found to charge excessive prices when its list prices are $\boldsymbol{X}$ percent greater than their average variable accounting costs. But this, as well as similarly arbitrary rules, will result in inefficient outcomes almost surely.

These difficulties have been understood by courts, policy makers, economists and legal scholars for a long time. The ECJ in United Brands noted that

the considerable and at times very great difficulties in working out production costs which may sometimes include a discretionary apportionment of indirect costs and general expenditure and which may vary significantly according to the size of the undertaking, its object, the complex nature of its set up, its territorial area of operations, whether it manufactures one or several products, the number of its subsidiaries and their relationship with each other, ... ${ }^{72}$

According to Esteva-Mosso and Ryan,

\footnotetext{
${ }^{69}$ I Vogelsang 'Incentive Regulation and Competition in Public Utility Markets: A 20-Year Perspective' (2002) 22 J Regulatory Economics 5.

${ }^{70}$ Ibid 9.

${ }^{71}$ Ibid 11.

${ }^{72}$ United Brands (n 9) 254.
} 
The determination of an exploitative effect necessarily involves, therefore, the need to make a subjective judgment as to the appropriate level of prices and output in a particular market. ${ }^{73}$

Likewise Whish comments,

Even if it is accepted ... that exploitative pricing should be controlled there is the difficulty of translating this into a sufficiently realistic legal test. A legal rule condemning exploitative pricing needs to be cast in sufficiently precise terms to enable a firm to know on which side of legality it stands. ${ }^{74}$

The OFT in its Draft Guidelines on the Assessment of Conduct states,

A profitability assessment [of excessive pricing] can require an element of judgment about the relevant rates of return, the valuation of assets, the appropriate cost of capital, and the appropriate cost and revenue allocation methods. $^{75}$

Some commentators have gone even further to discuss the implications of what we have termed an "impossibility theorem" for competition policy practice. But they have done so in a rather informal fashion and without reaching clear-cut normative recommendations. For example, Whish finds that

Given these problems, it is not surprising that competition authorities prefer to deploy their resources by proceeding against anti-competitive abuses that exclude competitors from the market rather than establishing themselves as price regulators. ${ }^{76}$

In a similar vein, Esteva-Mosso and Ryan noted,

The United Brands case highlights the major difficulties of proof associated with finding an abuse of excessive pricing, and probably explains the relative dearth of instances in which the Commission has intervened in those cases. ${ }^{77}$

Motta and de Streel concur,

\footnotetext{
${ }^{73}$ Esteva-Mosso and Ryan (n 61) 189. Emphasis added.

${ }^{74}$ R Whish Competition Law (4 ${ }^{\text {th }}$ edn Butterworths London 2001) 634-635.

${ }^{75}$ Assessment of Conduct (n 31) para 2.14.

${ }^{76}$ Whish (n 74) 635.

${ }^{77}$ Esteva-Mosso and Ryan (n 61) 192.
} 
[W]e suggest that the Commission uses its power with great parsimony and that the Court sets high level of proof. ${ }^{78}$

Indeed, the reaction of the Commission to these problems appears to be the adoption of a conservative approach in the application of Article 82(a). The Commission has stated that, even if it does not renounce to pursue excessive pricing cases,

its decision-making practice does not normally control or condemn the high level of prices as such. Rather it examines the behavior of the dominant company designed to preserve its dominance, usually directed against competitors or new entrants who would normally bring about effective competition and the price level associated with it. ${ }^{79}$

In sum, the consensus reaction to the impossibility result formally stated above is that Article 82(a) should be applied only in very obvious, serious and indefensible cases, in which the difficulty and imprecision of the tests cannot affect the validity of the conclusion. However, this approach is not objective and is likely to lead to inconsistent and inefficient decisions. How could a dominant firm be sure when designing its pricing policies that its case would be regarded as obvious, serious and indefensible? Clearly, this parsimonious approach is not workable. Hence, in the following two Sections, we take the discussion on the appropriate legal standard for excessive prices forward by applying a decision-theoretic approach that allows comparison of legal rules taking into account the possibility and welfare cost of error.

\section{Pragmatic Legal Rules}

In light of the "impossibility" result derived above, any pricing rule of the type "a price is excessive if it is $\boldsymbol{X}$ percent greater than cost" is bound to cause errors: supra-competitive prices will be blessed in some instances, while competitive prices will be condemned in others. ${ }^{80}$ Any legal standard for excessive pricing will therefore result in "false convictions"or "type I errors" in the standard terminology of decision theory—and/or "false acquittals"—or

\footnotetext{
${ }^{78}$ Motta and de Streel (n 60) 27.

${ }^{79}$ XXIVth Report on Competition European Commission (1994) 207.

${ }^{80}$ The same sort of errors will follow from a profit rule where excessive prices are identified by comparing the profits earned by a dominant firm with a "competitive” benchmark. In what follows, for simplicity, we will restrict attention to price-cost rules.
} 
“type II” errors. To use the criminal justice system as an example, a type I error would be the equivalent of jailing an innocent person, whereas a type II error would be allowing a guilty party to go unpunished.

In criminal law type II errors are generally taken to be less heinous, but as an empirical question it is not obvious which error type would be less desirable in general. It depends on the relative likelihood and welfare cost of each of the two types of errors. In what follows we argue that type I errors are potentially more serious than type II errors in excessive pricing cases, especially in dynamic industries where investment and innovation are the main drivers of a firm's market share and profitability.

\subsection{Type I and Type II Errors}

The cost of a type I error in excessive pricing cases is given by a reduction in the incentives to invest and innovate for firms that operate not only in the sectors where intervention takes place but all throughout the economy. Evidence of false convictions is bound to reduce the incentives to invest by reducing the expected rate of return on successful innovations. As illustrated in Figure 1 below, a tight policy regarding excessive prices is equivalent to the introduction of an upper bound to profits. Given that profits are uncertain ex ante, a firm would only be willing to invest if the expected return on its investment exceeds the cost of capital. In Figure 1, investment is profitable ex ante when the firm's pricing policy is unrestricted (where profits are given by the dotted-line distribution), but not when there is an upper bound on profits (as illustrated by the continuous-line distribution).

Figure 1. The effect of a stringent excessive pricing policy on investment

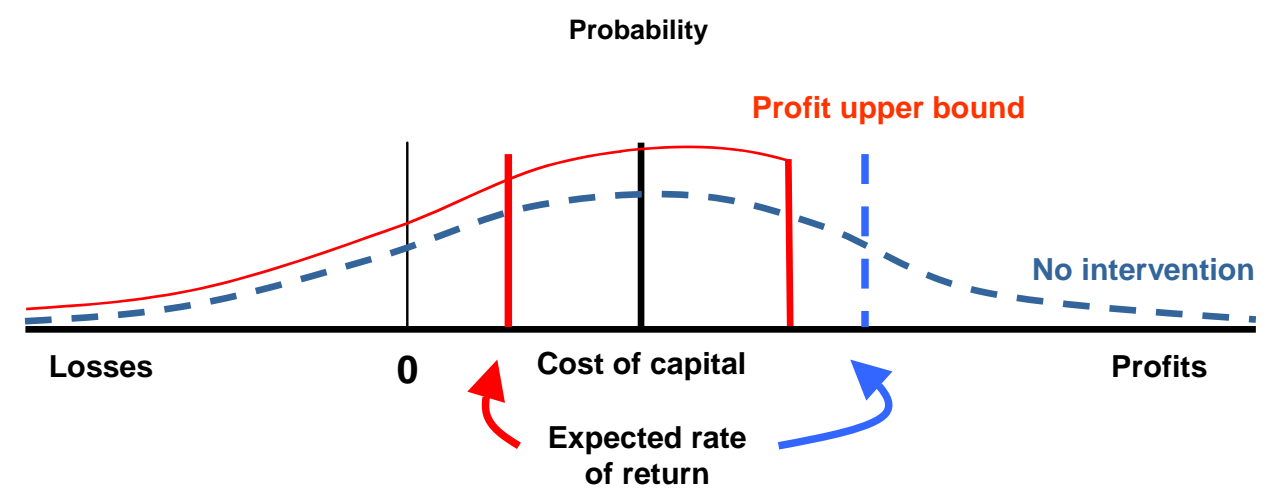


In welfare terms, therefore, the cost of a type I error is equal to the loss in consumer welfare resulting from the no introduction of valuable goods and services for which there is potential demand. This is given by area A in Figure 2. The cost of a type II error is equal to the loss of consumer welfare that results from supra-competitive prices, and which is given by two effects: (a) some consumers pay more than in an otherwise competitive market to obtain the good or service they wish, and (b) other consumers see themselves excluded from consumption despite their relatively high valuations. In Figure 2, these effects are given by areas B and C, respectively. The cost of a type II error is therefore equal to the sum of B and C.

Figure 2. The cost of type I and type II errors in excessive pricing cases

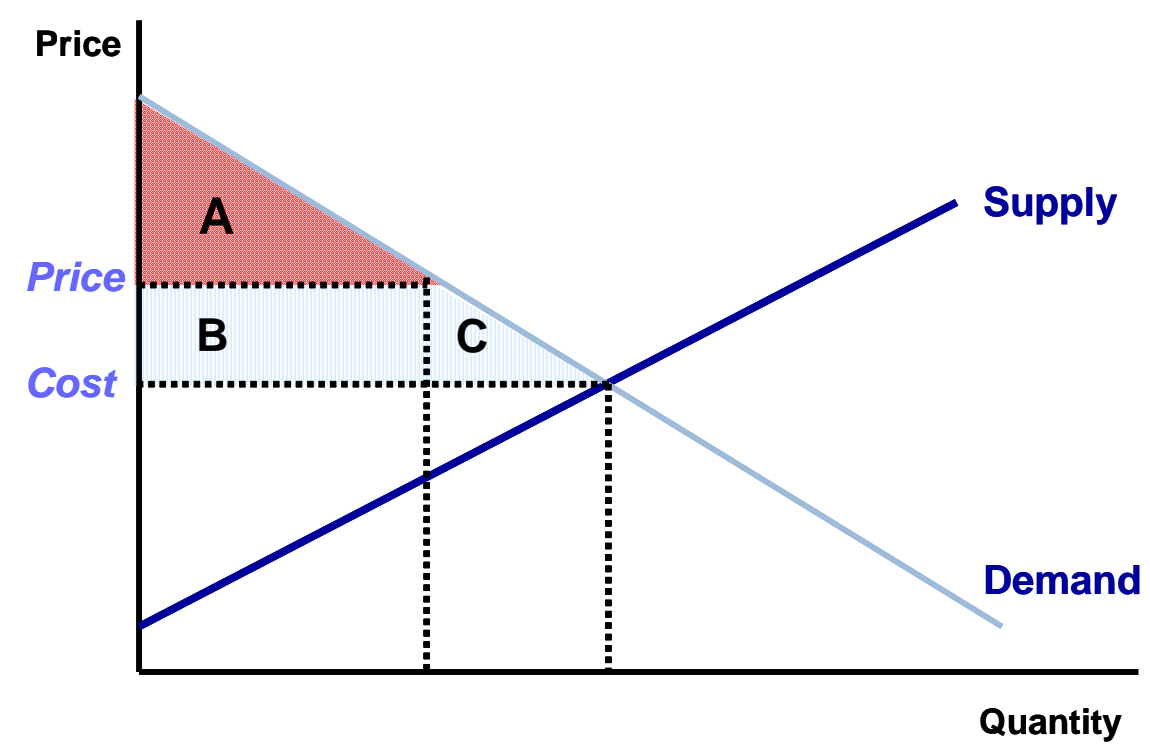

The cost of a type I error is likely to be large in dynamic industries where firms compete for the market launching new products and services, ${ }^{81}$ in emerging industries where firms are contemplating whether to start up, ${ }^{82}$ and in those mature industries where, due to

\footnotetext{
${ }^{81}$ The software and pharmaceutical industries constitute good examples. See Evans and Schmalensee (n 11); and G Baker 'Regulating Commercial Relationships and Uncertainty: A Regulatory Framework for Industries Facing Dynamic Change' Centre for Commercial Law Conference Faculty of Law-ANU (Canberra 30 September 2002) <http://law.anu.edu.au/cle/Papers/Law\&Econ-Conference.pdf> (26 July 2004).

${ }^{82}$ As it is currently the case in the biotechnology sector. Ibid.
} 
technological change, firms have the opportunity to upgrade their services. ${ }^{83}$ The cost of this type of error is bound to be large in industries where trial and error is common, in which the cost of experimentation is high, but the return to success is potentially huge. The music recording industry is an example in which the profits for a few blockbuster albums pay for the vast majority of unprofitable acts. In all those cases, the size of area A is likely to be large, whereas it will be small in mature or declining industries where investment is no longer a factor.

Type II errors are likely to be costly when the price-cost margin is large (so that area B is large) and the elasticity of demand is high (so that area $C$ is also large). Note, however, that the equilibrium price-cost margin is bound to be small when the elasticity of demand is high, ${ }^{84}$ which puts a limit to the likely cost of a type II error in excessive pricing cases. ${ }^{85}$

The costs of the type II errors are necessarily small in industries where there are no barriers to entry and in which short-term profits are competed away over time as new firms enter. The argument here is that with low barriers to entry, market forces can be relied upon to eliminate excess profits in a reasonable period of time, thus increasing the cost of intervention relative to its benefits. As a result, while type I errors will often have potential long-term and wide-ranging effects, type II errors are likely to be limited in their effect to the case at hand and are relatively short-term.

The likelihood of one or another type of error will depend on the precise specification of the pricing rule. Consider the rule stated above: “a price is excessive if it is $\boldsymbol{X}$ percent greater than cost." Type I errors are more likely when $\boldsymbol{X}$ is relatively small, and less likely when $\boldsymbol{X}$ is large. The opposite is true for type II errors. Type I errors will be more likely precisely in those cases where they are most costly, namely in dynamic industries and in industries where investment drives competition and welfare. It is in those industries where the welfare value of

\footnotetext{
${ }^{83}$ The telecommunications industry provides an example of a mature industry where competitors are currently engaged in massive investments to meet the so-called broadband revolution. See (n 12).

${ }^{84}$ Indeed, in a monopolistic equilibrium, the price-cost margin (p-c)/p is inversely related to the elasticity of demand. See M Waterson Industrial Economics (Cambridge University Press Cambridge 1984).

${ }^{85}$ Area B will tend to be small when Area C is large and vice versa.
} 
innovation (i.e., the size of area A) is larger, but where the price-cost margins that firms require to compete are also large.

\subsection{Design of Legal Rules}

Given these error calculations, what should be the most appropriate legal standard for excessive prices? In this Section, we analyze the optimality of alternative legal standards under the assumption that they apply to all industries and cases alike. In the next Section, we relax this assumption to consider the desirability of a more flexible standard that allows discrimination on a case-by-case basis.

There are several possible legal rules to be considered in principle, but only a few make sense in excessive pricing cases given the "impossibility" result in Section 4 and the discussion above on error costs and probabilities:

- Per se legality. Under this rule no price would ever be considered unfair or excessive.

- $\quad$ Modified per se illegality. Prices would be presumed illegal if they are $\boldsymbol{X}$ percent greater than cost. ${ }^{86}$ Defendants could rebut this presumption by providing evidence of significant ex-ante efficiencies.

- Structured rule of reason. This standard would employ a first screen to focus only on those industries where (a) barriers to entry are high and (b) ex ante investment and innovation incentives play no, or at least limited, role. ${ }^{87}$ In a second stage, it would involve a price-cost comparison like that under the modified per se illegality rule. Finally, in the last stage, offsetting ex-ante efficiency benefits would be considered and balanced against the ex-post distortions associated to high prices.

\footnotetext{
${ }^{86}$ A per se illegality rule would have $\boldsymbol{X}$ equal to zero, which is clearly suboptimal as it maximizes the likelihood of high cost type I errors, while it minimizes the likelihood of costless type II errors. A modified per se illegality rule where $\boldsymbol{X}$ is greater than zero would always be superior in welfare terms.

${ }^{87}$ Note that this screen is more stringent than the standard analysis of dominance, based on structural factors such as market shares and barriers to entry, as it involves investigating the mode of competition and, hence, the role of investment and innovation in shaping the future evolution of the market.
} 
It should be clear that, from an error cost perspective, the structured rule of reason standard is superior to the modified per se illegality rule. This is because the first screen of the rule of reason test narrows down the scope for intervention to industries where the cost and likelihood of a false conviction (type I error) are both low. Given that the second and third stages of the rule of reason standard are basically identical to the two stages of the modified per se illegality rule, we have that the latter will necessarily lead to more and more costly errors than the former.

Our choice of an optimal legal standard, hence, boils down to choosing between the structure rule of reason standard and the per se legality rule. One key factor in this comparison is obviously the assessment of the likelihood and cost of error under each of the two approaches. Another important factor in choosing between a rule of reason standard and a per se rule is the administrative and enforcement costs of implementing the legal standard. A per se rule is easier and cheaper to administer and enforce. ${ }^{88}$

A per se legality rule would result in more false acquittals (or type II errors), especially in industries where barriers to entry are high, but would cause no false convictions (or type I errors). A structured rule of reason standard would cause both type I and type II errors, although its first (or, industry analysis) and last (or, balancing test) stages would likely reduce the expected cost of the type I errors. Ultimately, however, the likelihood and cost of the type I and II errors under a rule of reason approach crucially depend on the actual formulation of the price-cost test in the second stage of the analysis: i.e., on the value of $\boldsymbol{X}$ that is finally chosen and on the precise definition of the terms "price" and "cost" to be used in practice. As we saw above, economic theory provides no guidance in this respect. Neither does the available case law. The only unambiguous conclusion that emerges from the economic literature and the case law is that distinguishing between competitive and supra-competitive prices is a daunting, if not impossible, task.

The increased cost of the false acquittals under the per se rule must therefore be compared to the cost of the additional administrative costs of having a rule of reason standard

\footnotetext{
${ }^{88}$ K. N. Hylton Antitrust Law, Economic Theory and Common Law Evolution (Cambridge University Press Cambridge 2003).
} 
as well as the costs of false convictions from applying that standard. The result of this comparison depends on prior beliefs concerning the expected costs of each type of error and the ability of the competition authorities and courts to separate welfare increasing from welfare reducing prices. ${ }^{89}$ Do we believe that above cost prices are generally efficient? ${ }^{90}$ Do we believe that the decisions of competition authorities and courts regarding excessive prices are likely to be accurate? A per se rule is most appropriate if one believes that pricing above cost is frequently welfare increasing and that the authorities and courts cannot accurately separate harmful from beneficial prices. In this case, it is better to approve all prices than to risk prohibiting many efficient pricing strategies only to catch a few harmful ones. (See Figure 3.)

We believe that the weight of the evidence favors a per se legal approach. Given the discussion in Sections 2 to 4, it seems obvious that the ability of competition authorities and courts (or indeed of any economist) to distinguish between efficient (fair) and inefficient (unfair) prices in practice is very low. Furthermore, we do believe that pricing above cost is generally efficient. ${ }^{91}$ The reason is twofold. First, firms need to mark up their variable costs in order to cover their fixed costs, to fund their new investments, and to continue innovating (i.e., the size of area A in Figure 2 is typically large). Second, the ability of firms to sustain supracompetitive prices is most often constrained by the possibility of entry (i.e., areas B and C are small). ${ }^{92}$

\footnotetext{
${ }^{89}$ For a formal approach to this issue, see K. N. Hylton and M. Salinger 'Tying Law and Policy: A DecisionTheoretic Approach’ (2001) 69 Antitrust LJ 469, 470-71.

${ }^{90}$ Likewise, do we consider that large profits most often remunerate large and risky investments?

${ }^{91}$ Different conclusions on the most appropriate legal standard would follow from alternative presumptions about error costs and probabilities. For example, John Fingleton, the Head of the Irish Competition Authority claims: "The big [competition] problems in Ireland, and probably in many other European countries, still stem from lack of effective sanction against monopolization, and not from any fear of excessive enforcement against firms that have obtained high market shares by virtue of vigorous competition and efficiency." J Fingleton 'Demonopolising Ireland' (6 June 2003) <http://www.tca.ie/speeches/presentations/florence_june_2003.pdf> (July 22, 2004).

${ }^{92}$ It could be argued that, given that attention is restricted to the pricing behaviour of dominant firms, entry is already taken into consideration in the assessment of dominance and that, consequently, competition authorities do restrict their attention to cases where areas B and C are likely to be large.
} 
Figure 3. The Choice of Legal Standard

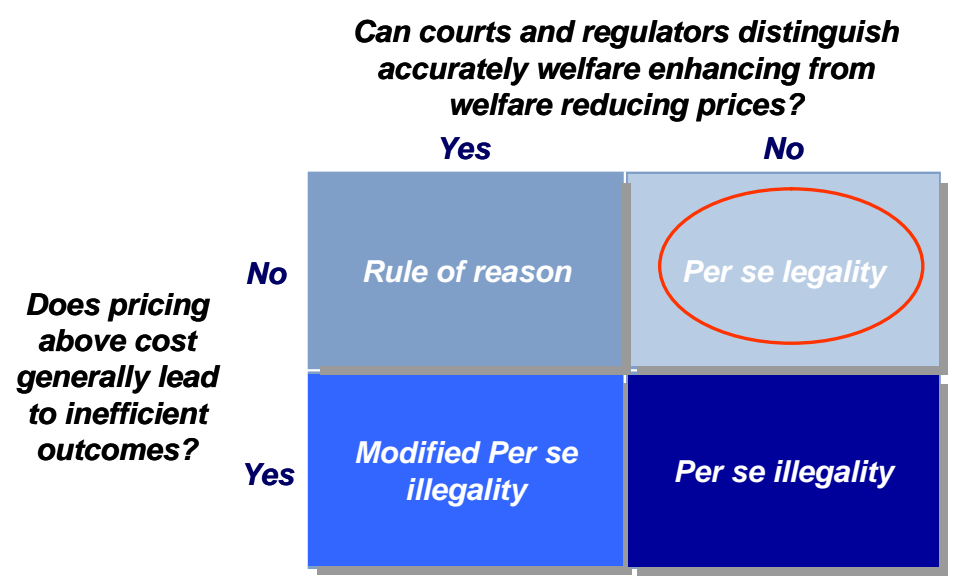

\section{Keeping Article 82(A) Alive?}

The advantage of specifying a common per se legal standard for all excessive pricing cases is that it greatly simplifies the application of the law, providing firms with a more certain legal environment and allowing competition authorities to focus on other more grievous offences. Yet, under some "exceptional circumstances" it may be preferable to adopt an interventionist approach towards excessive prices. Hence there may be a rationale for retaining Article 82(a) after all. These circumstances are: (a) the firm enjoys a (near) monopoly position in the market, which is not the result of past investments or innovations, and which is protected by insurmountable legal barriers to entry; (b) the prices charged by the firm widely exceed its average total costs; and (c) there is a risk that those prices may prevent the emergence of new goods and services in adjacent markets. ${ }^{93}$ These three conditions, which should be applied case by case, are cumulative: it is enough that one of them does not hold to conclude that prices are not "unfairly" high.

Conditions (a) and (b) taken together indicate that in the case at hand the expected cost of a false conviction (the size of area A) is relatively small, while the expected cost of a false acquittal (the size of $\mathrm{B}+\mathrm{C}$ ) is large. However, these two conditions are not enough to

\footnotetext{
${ }^{93}$ Note that this last condition corresponds to the ECJ's "new product test" in Magill (Joined cases C-241/91 and C-242/91 RTE and ITP v. Commission [1995] ECR I-743) and IMS Health (Case C-418/01 IMS Health GmbH \& Co OHG v. NDC Health GmbH \& Co KG [2004]).
} 
intervene. Note that the legal monopolist may be engaged in, or planning to undertake, costly investment projects that could be put at risk if prices were to be regulated. Hence, one cannot assume that even if conditions (a) and (b) hold, the cost of a false conviction is zero. This is why we introduce condition (c) as a way to ensure that the cost of a false acquittal is orders of magnitude much larger than the cost of false conviction. ${ }^{94}$

This modified per se legality standard, and the associated "exceptional circumstances" three stage test, is broadly consistent with the Commission's practice in General Motors and British Leyland..$^{95}$ In both cases, a car company charged a very high price for the production of documents that were necessary to import cars into a different Member State. The documents were cheap to produce but the value to consumers extremely high, as otherwise they would not be able to import their cars. As noted by Whish, in these cases, the Commission considered that the prices regarded as excessive "were imposed with the intention of impeding parallel imports and exports.”

Our proposed approach is, however, not consistent, at least not entirely, with proposals to use Article 82(a) to foster liberalization efforts on markets recently opened to competition, such as the telecommunications industry. ${ }^{96}$ The argument that is used to defend the introduction of an industry-specific standard for newly liberalized sectors is that dominant firms in those sectors often obtained their position not through superior efficiency but through State intervention, and that they are characterized by high barriers to entry so that supra-competitive profits will not attract new entrants. Although we agree that "appropriate public policy towards firms with actual or potential market power depends on the cause the market power," ${ }^{97}$ we do not concur with the implicit assumption that all firms with market power in newly liberalized

\footnotetext{
${ }^{94}$ John Vickers recently explained that the OFT's position on Napp’s alleged excessive prices would have changed radically if the pricing to the hospital segment was not judged to be exclusionary. We agree with his view, which nonetheless was rejected by the CCAT, that the existence of some form of exclusionary conduct is a prerequisite for a finding that prices are excessive. See J Vickers 'How Does the Prohibition of Abuse of Dominance Fit with the Rest of Competition Policy?' (6 June 2003). <http://www.oft.gov.uk/NR/rdonlyres/660C15CB-6F9E-41F5-A370-61F6EE022CB3/0/spe0303.pdf > (July 22, 2004)

${ }^{95}$ General Motors (n 16); British Leyland (n 16).

${ }^{96}$ See, for example, Motta and de Streel (n 60) 23.

${ }^{97}$ Vickers (n 94).
} 
sectors should be regarded a priori as "idle monopolists," even if they were at some point under State control. On the contrary, the evidence suggests that many incumbents in the telecom and energy sectors all throughout Europe invest vast amounts of money in competing with entrants. ${ }^{98}$

\section{Concluding REMARKS}

Unlike EC competition law, U.S. antitrust law does not prohibit excessive pricing. In Berkey Photo, Inc. v. Eastman Kodak Co., the Court of Appeals for the Second Circuit said,

Setting a high price may be a use of monopoly power, but it is not in itself anticompetitive ... Judicial oversight of pricing policies would place the courts in a role akin to that of a public regulatory commission ... ${ }^{99}$

Likewise, in Trinko, the Supreme Court stated,

The mere possession of monopoly power, and the concomitant charging of monopoly prices, is not only not unlawful; it is an important element of the freemarket system. The opportunity to charge monopoly prices-at least for a short period-is what attracts "business acumen" in the first place; it induces risk taking that produces innovation and economic growth. ${ }^{100}$

In this paper we have evaluated alternative legal standards towards excessive pricing by explicitly considering the likelihood of false convictions/acquittals and the costs associated with those errors. Our decision-theoretic analysis supports the per se legality standard adopted in the United States and suggests a way to reform the existing legal framework in the EU.

As Professor Fox noted a few years ago,

[T]he Common Market law on excessive pricing ... assumes that high pricing is unfair, it assumes that high pricing can be identified by courts, and it implies that that courts are better mechanisms than markets to correct unfairly high pricing.

\footnotetext{
${ }^{98}$ Ray Le Maistre 'Europe Doubles Down on DSL' (7 January 2004) <http://www.lightreading.com/document.asp?doc_id=45593\&site=lightreading> (28 July 2004).

${ }^{99}$ Berkey Photo, Inc v Eastman Kodak Co 603 F 2d 263, 294 ( $2^{\text {nd }}$ Cir 1979), cert denied 444 US 1093 (1980).

${ }^{100}$ Verizon Communications, Inc v Law Offices of Curtis V Trinko, LLP 157 L Ed 2d 823, 836 (2004).
} 
None of these assumptions is valid according to our analysis. As the U.S. Supreme Court stated in Trinko, high prices are not necessarily anticompetitive; instead they are often procompetitive, due to incentive effects. The case law shows that assessing excessive prices is an extremely complex task, subject to daunting conceptual and practical difficulties. It also shows that any rule that prohibits excessive prices is likely to yield incorrect predictions in numerous instances.

We have found a possible exception to our general recommendation of no intervention. Under some "exceptional circumstances" it may be appropriate public policy to interfere with the pricing policies of entrenched monopolies enjoying the protection of legal barriers to entry and whose actions may impede the launching of new products or the emergence of new, adjacent markets. But even in those cases, it remains unclear why it may not be better simply to rely on ex-ante regulation given that the sector-specific regulatory bodies have more information about the fundamentals of the markets in question and are in a better position to monitor compliance. 


\section{CEMFI WORKING PAPERS}

0101 Manuel Arellano: "Discrete choices with panel data".

0102 Gerard Llobet: "Patent litigation when innovation is cumulative".

0103 Andres Almazán and Javier Suarez: "Managerial compensation and the market reaction to bank loans".

0104 Juan Ayuso and Rafael Repullo: "Why did the banks overbid? An empirical model of the fixed rate tenders of the European Central Bank".

0105 Enrique Sentana: "Mean-Variance portfolio allocation with a Value at Risk constraint".

0106 José Antonio García Martín: "Spot market competition with stranded costs in the Spanish electricity industry".

0107 José Antonio García Martín: "Cournot competition with stranded costs".

0108 José Antonio García Martín: "Stranded costs: An overview”.

0109 Enrico C. Perotti and Javier Suárez: "Last bank standing: What do I gain if you fail?".

0110 Manuel Arellano: "Sargan's instrumental variable estimation and GMM".

0201 Claudio Michelacci: "Low returns in R\&D due to the lack of entrepreneurial skills".

0202 Jesús Carro and Pedro Mira: "A dynamic model of contraceptive choice of Spanish couples".

0203 Claudio Michelacci and Javier Suarez: "Incomplete wage posting".

0204 Gabriele Fiorentini, Enrique Sentana and Neil Shephard: "Likelihood-based estimation of latent generalised ARCH structures".

0205 Guillermo Caruana and Marco Celentani: "Career concerns and contingent compensation".

0206 Guillermo Caruana and Liran Einav: "A theory of endogenous commitment".

0207 Antonia Díaz, Josep Pijoan-Mas and José-Víctor Ríos-Rull: "Precautionary savings and wealth distribution under habit formation preferences".

0208 Rafael Repullo: "Capital requirements, market power and risk-taking in banking".

0301 Rubén Hernández-Murillo and Gerard Llobet: "Patent licensing revisited: Heterogeneous firms and product differentiation".

0302 Cristina Barceló: "Housing tenure and labour mobility: A comparison across European countries".

0303 Víctor López Pérez: "Wage indexation and inflation persistence".

0304 Jesús M. Carro: "Estimating dynamic panel data discrete choice models with fixed effects".

0305 Josep Pijoan-Mas: "Pricing risk in economies with heterogenous agents and incomplete markets".

0306 Gabriele Fiorentini, Enrique Sentana and Giorgio Calzolari: "On the validity of the Jarque-Bera normality test in conditionally heteroskedastic dynamic regression models".

0307 Samuel Bentolila and Juan F. Jimeno: "Spanish unemployment: The end of the wild ride?". 
0308 Rafael Repullo and Javier Suarez: "Loan pricing under Basel capital requirements".

0309 Matt Klaeffling and Victor Lopez Perez: "Inflation targets and the liquidity trap".

0310 Manuel Arellano: "Modelling optimal instrumental variables for dynamic panel data models".

0311 Josep Pijoan-Mas: "Precautionary savings or working longer hours?".

0312 Meritxell Albertí, Ángel León and Gerard Llobet: "Evaluation of a taxi sector reform: A real options approach".

0401 Andres Almazan, Javier Suarez and Sheridan Titman: "Stakeholders, transparency and capital structure".

0402 Antonio Diez de los Rios: "Exchange rate regimes, globalisation and the cost of capital in emerging markets".

0403 Juan J. Dolado and Vanessa Llorens: "Gender wage gaps by education in Spain: Glass floors vs. glass ceilings".

0404 Sascha O. Becker, Samuel Bentolila, Ana Fernandes and Andrea Ichino: "Job insecurity and children's emancipation".

0405 Claudio Michelacci and David Lopez-Salido: "Technology shocks and job flows".

0406 Samuel Bentolila, Claudio Michelacci and Javier Suarez: "Social contacts and occupational choice".

0407 David A. Marshall and Edward Simpson Prescott: "State-contingent bank regulation with unobserved actions and unobserved characteristics".

0408 Ana Fernandes: "Knowledge, technology adoption and financial innovation".

0409 Enrique Sentana, Giorgio Calzolari and Gabriele Fiorentini: "Indirect estimation of conditionally heteroskedastic factor models".

0410 Francisco Peñaranda and Enrique Sentana: "Spanning tests in return and stochastic discount factor mean-variance frontiers: A unifying approach".

0411 F. Javier Mencía and Enrique Sentana: "Estimation and testing of dynamic models with generalised hyperbolic innovations".

0412 Edward Simpson Prescott: "Auditing and bank capital regulation".

0413 Víctor Aguirregabiria and Pedro Mira: "Sequential estimation of dynamic discrete games".

0414 Kai-Uwe Kühn and Matilde Machado: "Bilateral market power and vertical integration in the Spanish electricity spot market".

0415 Guillermo Caruana, Liran Einav and Daniel Quint: "Multilateral bargaining with concession costs".

0416 David S. Evans and A. Jorge Padilla: "Excessive prices: Using economics to define administrable legal rules". 